\section{KNOWLEDGE ON ENVIRONIMENTAL HAZARDS AMONG SECONDARY SCHOOL STUDENTS OF RAIMANATHAPURAM DISTRICT- A STUDY}

KEY WORDS: environmental hazards, natural hazards and man - made hazards, student knowledge, student attitudes and environmental awareness

\section{Radha.M*}

\section{Dr.G.Sivakumar}

Research Scholar, College of Education, Alagappa University, Karaikudi, Tamil Nadu, India. *Corresponding Author Assistant Professor In Education, College of Education Alagappa University, Karaikudi,Tamil Nadu, India

This study is described to learn Knowledge on environmental hazards to the Secondary School Students. Environmental hazards are increasing due to both natural and man induced activities ever than before. A hazard is any types of threat or danger to human lives, livelihoods, economy, and society in the modern societies. Natural hazards like floods, droughts, landslides, cyclones etc. cannot be eliminated. Therefore, impact of hazards especially droughts and floods could have been reduced as they could forecast well and prepared for it. But at present indigenous knowledge is not used for forecasting due to various reasons such as change in lifestyles, technology, climate change etc. The secondary school students were found to possess substantial knowledge on environmental issues and good attitudes towards the environment. However they have moderate awareness on environmental issues and promote environmental awareness as they teach any related environmental topics given the significant role of knowledge in fostering environmental hazards among students.

\section{INTRODUCTION:}

This paper narrates an investigative study on Knowledge on Environmental Hazards among Secondary school Student. In our country,Environmental Hazards generate to end angerment to human life and infrastructures. Risk are the potential or possibilities that something bad will happen because of the hazards. (John Perritano, 2010) Some hazards are obvious such as earth quake, tornadoes, oil spills, and floods. There is no doubt that there hazards impact of people, animals, plants and the management of the natural.Hazard is natural or man-induced processes or events that cause potential losses to human lives, property damage, disruption to normal activities and essential functions of the community and damage to the environment. (Edward 2019). Natural hazards are responsible for causing significant death and damage worldwide each year. Process that cause hazards events include those internal to the earth, such as volcanic eruption and earthquakes that result from earth's such as hurricanes and global warming which are driven by energy from the sun. (Thomas measham 2012). Environmental issues from global warming to food and energy are intrinsically related to risk. At that same time, each of these global issues manifests itself as a local challenge. (Donald Hyndman 2009). The type of damage sustained as a result of a natural disaster also depends on the economic department of the area where it occurs. In developed countries there are typically greater economic losses, which developing countries, there are increasing number of deaths from natural disasters. So, knowledge of environment hazard is needed for all the people, but it is mainly important for school students.

\section{STATEMENT OFTHE PROBLEM:}

(Ashwatha Pratha et.al 2019) Environmental hazards are events developing from interactions between natural, social, and technological systems of the environment which are harmful to humans. By educating the students, correct preventive behaviour can be introduced starting from their home, thereby introducing in the society later. Thus, protecting our environment must begin from the basic education to school students and this is considered to be the newest and most effective method to protect our nature. Therefore the investigator has deliberate to study the Knowledge on environmental hazards among Secondary School Students of Ramanathapuram District.

\section{III.DEFINITION OF KEY TERM:}

\section{KNOWLEDGE:}

Knowledge is familiarity with someone of something, that can include facts, description, information, and or skills acquired through experience education. It can refer to the theoretical / practical understanding of a subject. (Keith smith 2009)

\section{ENVIRONIMENTAL HAZARD:}

"Environmental hazards refer to all the potential threats facing human society by events that originate in and are transmitted through the environment". (Sharmila 2017)

\section{SIGNIFICANCE OF THE STUDY:}

(Sharmila 2017) The need for knowledge of environment arises from the fact environmental hazards created by the rapid pace of development in the world have gone up to alarming levels, thereby making it difficult for the authorities to handle it on their own. To restore the quality of the environment in which we live and also to keep them in safe manner for the generations to follow essential that we undo the wrong being done, at the earliest in the most effective manner. For which have to maximize efforts from all guides in this direction to conserve and develop all the natural resources already existing and cause ass little disturbance as possible which much serve as precondition for improving the stability of ecology. The sources from which such problems arise have to be approached and given the required amount of knowledge, which clearly explains the need for environmental education. The programmes could be organized as environmental symposiums, seminars, workshops and/or conferences which would create an enabling environment for environmental health and safety experts to interact with students. More so, there could be implementation of existing environmental policies or formulation of new policies that could eliminate environmental hazards and risks in educational institutions.Moreover students are the nation builders of tomorrow and are the crucial part of our community. (Radha\& Sivakumar . 2021) Environmental awareness is to perceive and the weakness of our environment and the importance of its protection. Promoting environmental awareness is an easy way to become an environmental stewed and participates in creating a brighter future for our students. So, Everyone should have the necessary of knowledge to make preserving environment for our well being and also for the future generations.

\section{V.OBJECTIVES OFTHE STUDY:}

- To find out knowledge on environmental hazards among secondary school students

1. Gender

2. Locality

\section{HYPOTHESES OF THE STUDY:}

- There is no significant difference in knowledge on environmental hazards among school students with reference to their gender.

There is no significant difference in knowledge on Environmental hazards among secondary school students with reference to their locality. 


\section{METHODOLOGY:}

The investigator used the survey method in this study. The survey method is aimed at finding out an Knowledge on environmental hazards among school students. In the simplest way, the research is a plan structure and strategy of investigation in order to answer the research question. The investigator has planned structure strategy together data for their study.

\section{SAIMPLING TECHNIQUE:}

The research work using random sampling technique. After selecting 50 Students were selected randomly from the Secondary School Students.

\section{SATISTICAL TECHNIQUES USED FOR THE PRESENT STUDY:}

Descriptive and differential statistics were used for analysis data, secondary school students't' test was employed to find out the difference in various aspects from the level of knowledge on environmental hazards including gender and locality of students.

\section{XI.TOOLS USED INTHE STUDY:}

The following tools are used in the present study knowledge on Environmental hazards test constructed and validated by the Investigator.

\section{ANALYSIS AND INTERPRETATION OF DATA:}

For analysis and interpretations of data, the relevant input and analytical finding and inferences derived have been presented in different tables and their discussion provided after the table;

\section{HYPOTHESIS -}

1 There is no significant difference in knowledge on environmental hazards among secondary school students

\begin{tabular}{|c|c|c|c|c|c|}
\hline Variables & No & Mean & S.D & ' t 'value & Sig. level \\
\hline Boys & 22 & 86.5 & 8.1 & 0.33 & NS \\
\hline Girls & 28 & 87.4 & 10.5 & & \\
\hline
\end{tabular}

From the above table, it is observed that the mean of knowledge on environmental hazards score for secondary school students of boys and girls are 86.5 and 87.4 respectively The calculated ' $t$ ' value is 0.33 is less than the table value 2.00 at 0.05 level. Therefore, the formulated hypnosis, There is no significant difference of knowledge on environmental hazards among secondary school students with reference to their gender is accepted.

\section{HYPOTHESIS - 2}

There is no significant difference in knowledge on environmental hazards among secondary school students

\begin{tabular}{|c|c|c|c|c|c|}
\hline Variables & No & Mean & S.D & 't 'value & Sig. level \\
\hline Urban student' & 30 & 89.9 & 12.9 & 0.58 & NS \\
\hline Rural students & 20 & 87.62 & 14.3 & & \\
\hline
\end{tabular}

From the above table, it is observed that the mean of knowledge on environmental hazards score for secondary school students of urban and rural are and respectively The calculated't' value is 0.58 is less than the table value 2.00 at 0.05 level. Therefore, the formulated hypnosis. There is no significant difference of knowledge in environmental hazards among secondary school students with reference to their locality is accepted.

\section{LIMITATION:}

- The study was constricted only to the Secondary School Students in Ramanathapuam District, Tamilnadu.

- The sample was constricted only few schools in Ramanathapuram District, Tamilnadu.

- The study was constricted only 50 samples in Ramanathapuram District,Tamilnadu.

- The demographical variables were constricted only to gender and locality.

\section{AREAS FOR FURTHER RESEARCH:}

- The present study was constricted to the only Secondary School Students.This study can be enlarged for various type of colleges and Universities etc.

\section{XV.CONCLUSION:}

Environment is term stands for surroundings. Which includes various interrelated physical, biological and cultural elements around man at its centre. All these components are interrelated with one another dynamically. The world is concerned about the environmental problems. So the environmental education is needed for students in secondary level. It is to improve physical, social, biological and cultural environment. Which develop an awareness of environment and sensitivity to the total environment and its allied problems. The organisational climate of a school is the significant factor which contributes in the development of child personality and developing in the child awareness and understanding of the physical and social environment in its totality.

\section{REFERENCES:}

1. Keith Smith , N. David , and Petley (2009) . Environmental hazards (Assessing risk and reducing disaster) $07-08$

2. Edward , A. Kellen and Duane(2019) . Natural hazards : Earth's processes as hazards disasters \&

3. Robert N. Golden. Johan Perritano (2010). The truth about Environmental hazards $01-02$

4. Doinald Hyndman and David Hyndman (2009). Natural hazards and Disasters 03-04

5. Thomas Measham and Stewart Lockie (2012). Risk and Social theory in Environmental management 07-08

6. Sharmila V. (2017) Predictive correlates of the knowledge of natural hazards, Ecosystem and Global warming 24 - 33

7. Ashwatha pratha.A (2019) Awareness on Environmental hazards $08-09$

8. Radha.M and Sivakumar.G (2021) Psychology and Education: Awareness on Environmental Protection 58 (2). 